\title{
3 \\ Lag fever, flash men, and late fashionable worlds
}

\author{
Clara Tuite
}

Our story starts not in the southern colonies but with a canonical scene of literary expatriation and scandalous celebrity: Lord Byron in Genoa, spending the spring of 1823 with the so-called 'Blessington circus', a tight little entourage of idler-adventurers who cast their web across Ireland, England, and continental Europe. The 'circus' was named for the Irish author and literary hostess Marguerite Gardiner, Countess of Blessington, and her second husband, Charles John Gardiner, the Earl of Blessington. It also included Blessington's daughter, Lady Harriet Gardiner, and Alfred, Count D'Orsay Marguerite's companion, supposed lover, and surrogate son, supposedly the Earl's lover as well, and Harriet's husband for a few years. It was a tangled web they wove.

Lady Blessington had a shadowy past. Born Margaret Power in Tipperary, she had been married off young by her father, an abusive minor landowner. Having left her drunken husband, she later became, as she put it, 'that despised thing, a kept mistress', excluded from respectable London society even after her marriage to Blessington in $1818 .{ }^{1}$ In autumn 1821 , she met twenty-year-old Alfred, the second son of a general in Napoleon's Grand Armée. Alfred had taken up a position in the army of the restored Bourbon monarchy, but in 1823 resigned his commission to travel with the Blessingtons in Italy and France. A spectacularly beautiful Regency Adonis, D'Orsay was known as 'the king of dandies', with all the ambiguity that entails: 'mannish rather than manly', he was 'resplendent like a beetle' and 'like some gorgeous dragonfly skimming through the air'. ${ }^{2}$ Representations of D'Orsay often featured him on horseback, as in the background of the 1834 lithograph by the Irish artist Daniel Maclise, published in Fraser's Magazine (Figure 3.1).

The story goes that the Blessington circus turned up on Byron's doorstep one afternoon, accidentally on purpose in the rain. At first, Byron avoided meeting them; thereafter, he was punctiliously effusive with Lady Blessington but far more interested in D'Orsay, of whom he said, 'having lived so long out of the world, it was rather an amusement to see what sort of an animal 


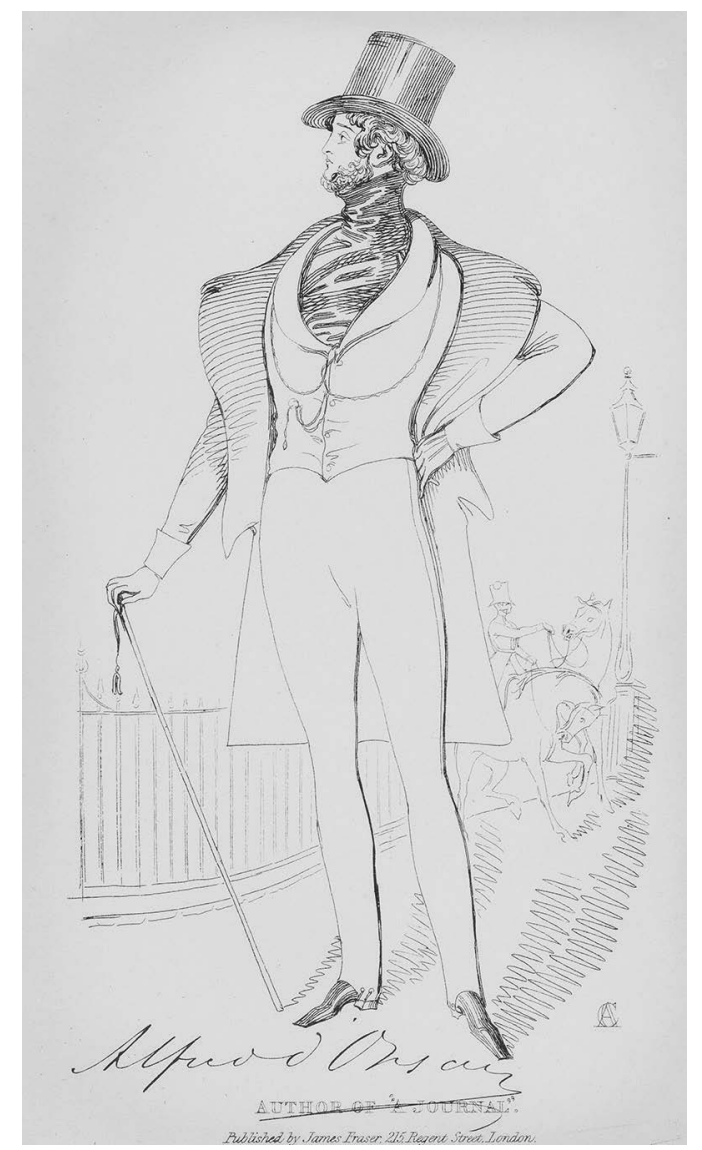

Figure 3.1 Daniel Maclise, 'Alfred, Count D’Orsay', lithograph, 1834

a dandy of the present day is'. He later described D'Orsay as re-fashioning 'an ideal of a Frenchman before the Revolution' - that is, an ornamented style of dandy, not the impeccably restrained kind invented by Beau Brummell in Mayfair in the 1790s. ${ }^{3}$ D'Orsay himself produced several well-known images of Byron during his association with the Blessington circus, including an ink and gilt silhouette (Figure 3.2) and a pencil sketch, reworked in 1832 (Figure 3.3) to illustrate Blessington's Conversations of Lord Byron, which was serialised in the New Monthly Magazine in 1832-33 and published in one volume in $1834 .{ }^{4}$ Career exiles all, Blessington, Byron, and D'Orsay embodied new possibilities of upward social mobility forged through glamorous scandalous celebrity.

My chapter traces the relationship between this celebrity European self-exile and the enforced mobility associated with penal transportation to 


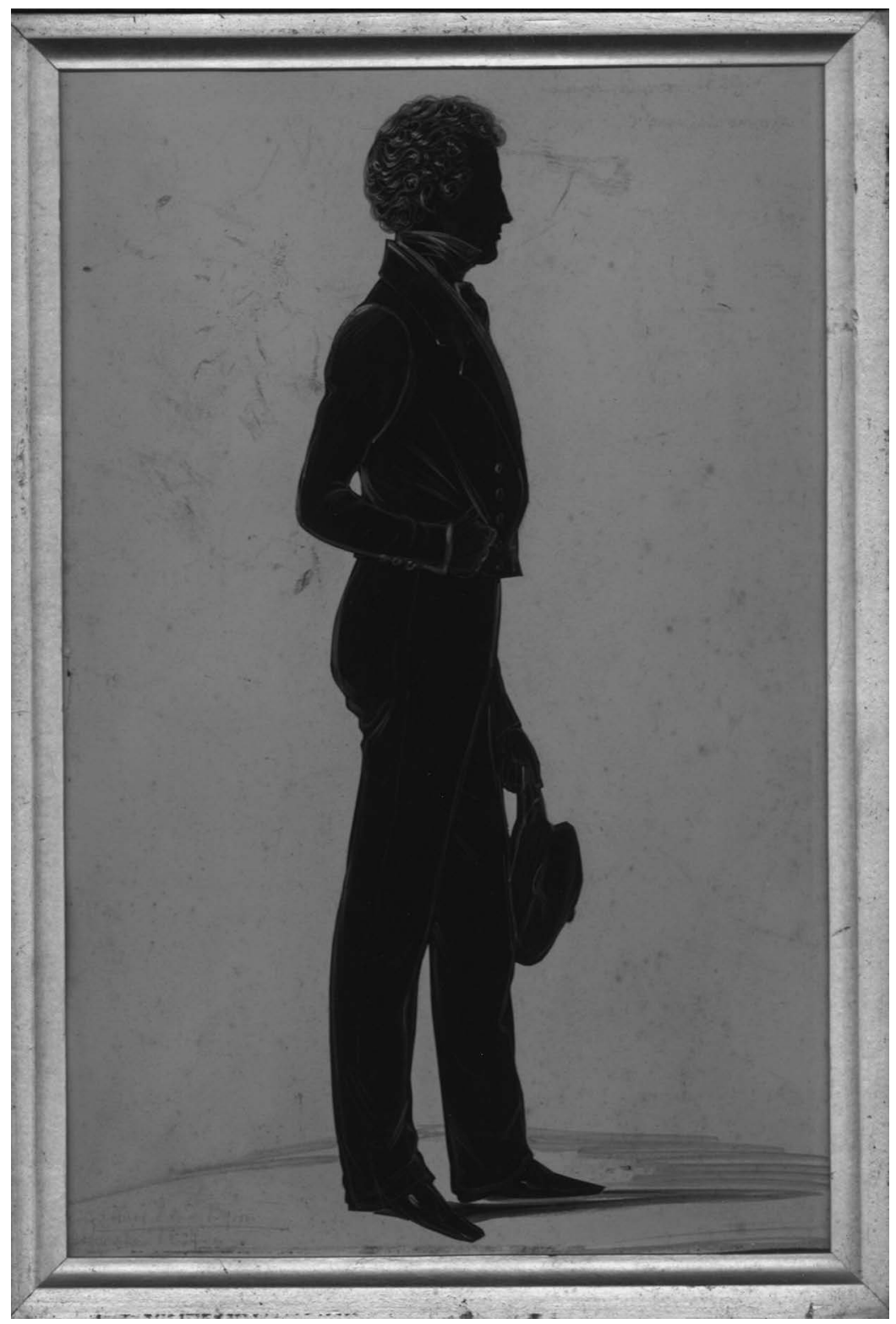

Figure 3.2 Count Alfred D’Orsay, 'Lord Byron', ink and gilt silhouette, 1823? 


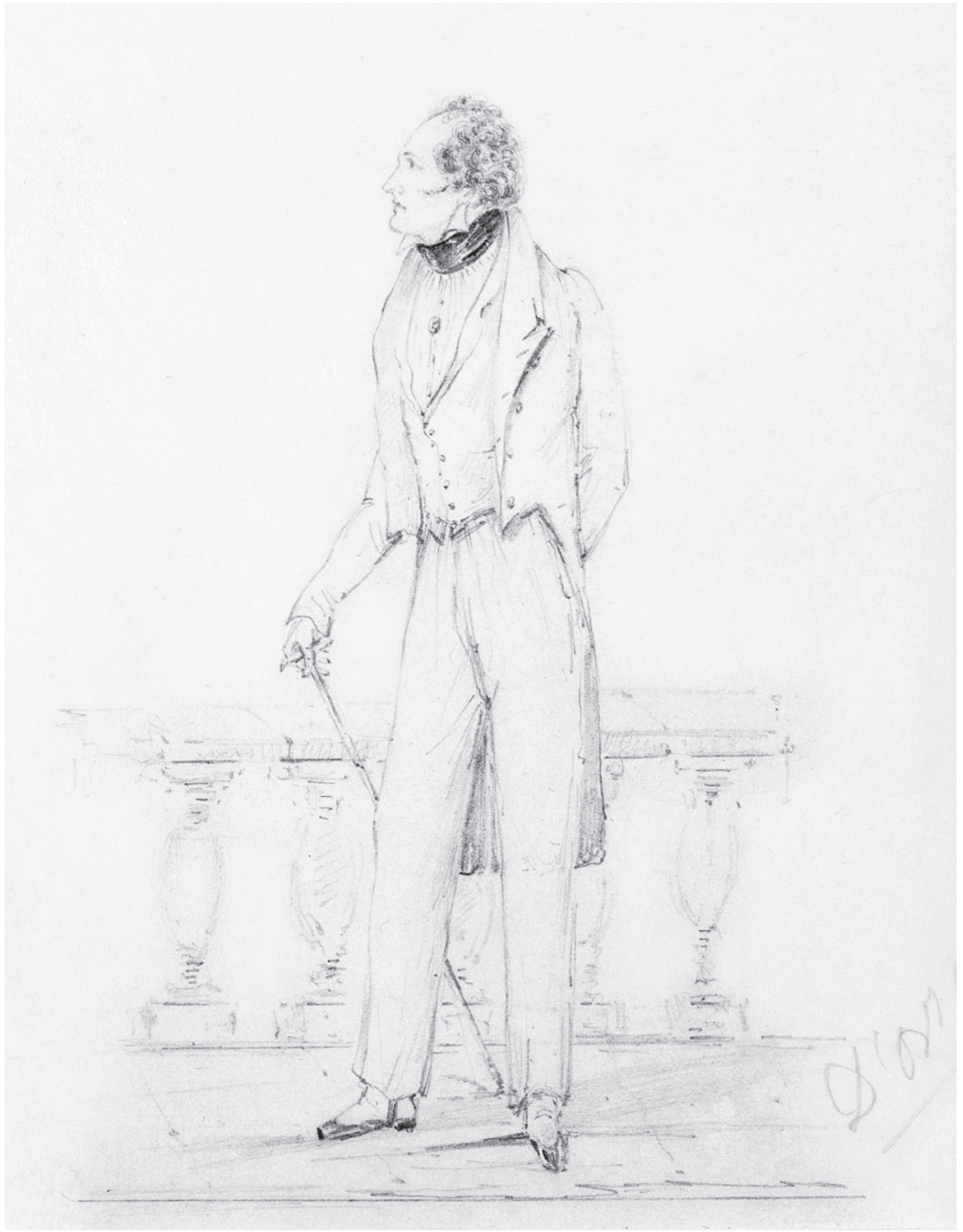

Figure 3.3 Count Alfred D’Orsay, 'Byron at Genoa', pencil sketch, 1823 (published 1832)

Australia and the settler culture that oversaw it. I explore circuits of scandalous celebrity, unrespectability, exile, expatriation, convictism, and settler culture; careers of upward and downward mobility; and the interpenetrations of colonial Australian and London metropolitan life. I examine the transportation and transformation of the social identity of the dandy, and of what we might call the dandy silhouette, which may be as precise as what Christopher Breward calls the 'Londonate' look of Beau Brummell in the 
Regency period. ${ }^{5}$ Here, D'Orsay's portrait of Byron functions as a 'silhouette' in the symbolic sense of a prototype of the Regency dandy that travelled across London and Europe to Botany Bay, Newcastle, and Van Diemen's Land.

Dandyism is usually regarded as a European phenomenon; but as Jessica Feldman argues, 'displacement' and 'international proliferation' are crucial to 'placing' it. Dandyism, she writes, 'exists in its purest form always at the periphery of one's vision, often in a foreign language or a text requiring decipherment'. ${ }^{6} \mathrm{~A}$ vital form of dandyism as a coded language is 'the flash', a 'foreign' language of thieves and gypsies, also known as 'St. Giles' Greek' after the London district associated with vagrancy. ${ }^{7}$

During the Regency, the flash language of the London criminal class was made over into a fashionable language and sociable style that linked it with the 'ton' and 'the world'. It took on new and intriguing infusions when it travelled to an antipodean setting from the late 1780s. As the colonial surgeon Peter Miller Cunningham wrote in Two Years in New South Wales (1827):

A number of the slang phrases current in St Giles's Greek bid fair to become legitimised in the dictionary of this colony: plant, swag, pulling up, and other epithets of the Tom and Jerry school ... In our police-offices, the slang words are regularly taken down in examinations ... Among the lower classes, these terms form a part of every common conversation; and the children consequently catch them. In addition to this, the London mode of pronunciation has been duly ingrafted on the colloquial dialect of our Currency youths! ${ }^{8}$

The flash mediated between elite culture and the underworld as a kind of classless language, equally fascinating to an elite worldly subject such as Lord Byron, the popular antiquarian Francis Grose in his Classical Dictionary of the Vulgar Tongue $(1785,1811,1823)$, and the transported convict James Hardy Vaux, whose Vocabulary of the Flash Language (1819) has the distinction of being the first Australian dictionary. Grose and Vaux were primary sources for Byron's 'flash' Canto XI of Don Juan. My chapter engages the 'flash' as an exotic hybrid, a kind of world language of the underworld that connects Regency London to glamorous-scandalous European exile, late grand-tourism, and the enforced mobility of penal transportation, mediating transnational circuits of masculine social identity and connecting convict culture to fashion and to new worlds of social mobility.

Another social identity that the flash language commemorates is the lag, variously defined as 'a man transported', 'a convict under sentence of transportation', a returned transport or ticket-of-leave convict, or someone avoiding the enforced mobility of penal transportation. ${ }^{9}$ A potent coinage of the flash language is 'lag fever': 'A term of ridicule applied to men who being under sentence of transportation, pretend illness, to avoid being sent from 
the gaol to the hulks.' ${ }^{10}$ This idea of 'lag fever' speaks to the stigma of convictism and to the sense of the colonial south as a world of backwardness, regression, and delay.

The 'lag ship' was 'a transport chartered by Government for the conveyance of convicts to New South Wales; also, a hulk, or floating prison, in which, to the disgrace of humanity, many hundreds of these unhappy persons are confined, and suffer every complication of human misery'. ${ }^{11}$ The hulks were rightly feared. In 1776, after American independence halted transportation to America, convicts sentenced to hard labour were crowded into decommissioned warships, which were used as floating prisons. After a 1778 inquiry exposed the horrendous conditions on the hulks, the authorities decided that 'Australia provided a possibility for the resumption of transportation, which no longer seemed so bad now that the alternatives had been explored'. ${ }^{12}$ The hulks now became the first stage of transportation. Convicts were then moved to the ships that would take them on the long journey to Australia, where they would remain until they were released. The first convicts to Australia arrived in Botany Bay in 1788 .

After the flash coves moved south from the London hulks, St Giles' Greek became 'ingrafted' on the tongue of the local Australian dialect and vice versa. One such ingrafting, as though lugubriously commemorating the long sea journey, or perhaps just the stasis of the hulks, is the flash word for spectacles, 'BARNACLES', after the marine crustaceans that cling to the bottom of ships, or the human attendants that cannot be easily shaken off. ${ }^{13}$ Flash glasses are laggers too, it seems, as are flash shoes, 'crabshells', another crustacean form, fashioned to fit the sideways movement from one place to another. ${ }^{14}$

In the original 1785 Grose's Classical Dictionary, 'lag' meant 'to lag, to drop behind, to keep back', and the lag as a subject was 'the last of a company.${ }^{15}$ By 1811, it took on the extra meanings associated with transportation to New South Wales. In using the flash coinage 'lag fever' to revisit conceptions of colonial belatedness, I highlight the transformative elements of lag and seek to illuminate the flash as a form of popular Romantic retrospective avant-gardism. I read the flash language, then, as the index of a late fashionable world of expatriated Regency dandyism. I read it, too, for its agential power, as a random collection of 'late fashionable words' (as Grose called it) that is also world-making: anachronistically sustaining, moving in and out of 'the world' of elite Regency London, travelling south in 'crabshells' in subversive refractions of the world-system of the British Empire, and celebrating the powers of ancient slang in a new time and place. ${ }^{16}$

The convict lagger is a kind of idler, too, but different from the glamorous idlers of Lord Byron's Hours of Idleness (1807) or Lady Blessington's The Idler in Italy (1839-40) and The Idler in France (1841). Indeed, the colonial 
lag was often both a labourer and a dandy, with claims to social respectability. Penal transportation and punitive convict mobility were a world apart from free settler movement or Byronic self-exile. But the culture of the flash, mediating Mayfair and cockney dandyism in expatriated and colonial convict forms, suggests that the convict lag has surprising connections to the European idler.

\title{
'Gentlemen of the shade': Byronic flash and transportation
}

In April 1823, when Byron was in Genoa, going out for morning rides with the Blessington circus, he was also revising Canto XI of Don Juan, the so-called 'flash' canto, and revisiting London in the company of Juan. When Juan arrives, he comes through Shooter's Hill on the outskirts of London, with its gallows at the foot and its gibbet at the summit, framing the vision of London as the capital of the British Empire through its sites and implements of punishment, part of Don Juan's wide-ranging critique of Tory England: 'Alas! Could She but fully, truly, know / How her great name is now throughout abhorred ... How all the nations deem her their worst foe, / That worse than worst of foes, the once adored / False friend, who held out freedom to mankind, / And now would chain them, to the very mind' (DJ X, st. 67 , lines $529-36) .{ }^{17}$

Accompanying this critique is a picaresque narrative of Juan's adventures in London. After his arrival, Juan is waylaid by Tom, the highwayman, or 'footpad' robber, who holds him up with a knife. Juan pulls out his gun and shoots Tom dead, while he is in 'Full flash' (DJ XI, st. 17, line 135), and then regrets it. Speaking as Juan in an intimate piece of indirect discourse, Byron's narrator notes:

\author{
Juan, who saw the Moon's late minion bleed \\ As if his veins would pour out his existence, \\ Stood calling out for bandages and lint, \\ And wished he had been less hasty with his flint.
}

(DJ XI, st. 14, lines 109-12)

Canto XI deploys flash vocabulary with its rich strain of demotic bravura, linguistic wit, and inventiveness, while reworking the Shakespearean intertext of Falstaff's appeal to Hal (in Henry IV, Part I): 'Marry, then, sweet wag, when thou art king ... let us be Diana's / foresters, gentlemen of the shade, minions of the / moon' (I. ii. lines 23-7).

Thieves had already been renamed with honorifics in William Harrison's Description of England (1577), which is part of Holinshed's Chronicles, a source for Henry IV. Grose's Classical Dictionary, the Bible of flash, invokes Falstaff to justify its use of rude words: 'with great truth [I] make 
the same defence that Falstaff ludicrously urges in behalf of one engaged in rebellion, viz. that he did not seek them, but that, like rebellion ... they lay in his way, and he found them'. ${ }^{18}$ Don Juan reworks the Shakespearean scene into a contemporary picaresque. As Tom dies, Juan sees 'the Moon's late minion bleed / As if his veins would pour out his existence'. To be a late minion is to be recently deceased, but also a lag. Saluting the fallen flash man, this passage recirculates an earlier form of thief's language that Shakespeare honours; and, like Shakespeare, it exalts the thieves, lyricises their work, and pays tribute to their aspirations to gentility. These 'gentlemen of the shade' are shadowy characters - secret, subversive, poetically associated with the night and the queen of the moon, Diana, and also with 'moon men' and link boys, as Grose defines them: 'link boys are said to curse the moon, because it renders their assistance unnecessary: these gentry, frequently under colour of lighting passengers over kennels, or through dark passages, assist in robbing them'. ${ }^{19}$

Social elevation through disguise is a vital element of flash culture. Indeed, the elevation of thieves is a primary story of Australian colonial history, marking the transformation of convict into settler, at first stealing silk handkerchiefs, then purchasing them. With the institution of transportation, the language of thieves became the language of convicts, transported to a place where everything is 'Opposite to England \& ... even the Moon is Top side Turvy your summer our winter', ${ }^{20}$ Transplanting the customary heroic association between banditry and moonlight, the late-nineteenth-century Victorian bushranger Captain Moonlite continues this tradition of Diana's foresters as a flash 'minion of the moon'.

Captain Francis Grose was familiar with the colonies through his son, Francis, who was Lieutenant Governor of New South Wales from 1792 to 1794, succeeding the first governor, Arthur Phillip. Francis Grose was a lax and indolent governor who abolished civil courts and established military rule, winding back the public farming that was a primary mode of convict labour and colonial development. He made generous land grants to his officers, including John Macarthur, whom he appointed the inaugural inspector of public works; and his own substantial reserve, Grose Farm, eventually became the grounds of the University of Sydney. ${ }^{21}$

The Regency moment of flash language and style hosted an abundance of new styles of masculine self-fashioning, cosmopolitan and colonial modes of fashionability, and new social types. Many flash coinages are not just new words but new social identities: a 'FLASH [is] a person who affects any peculiar habit, as swearing, dressing in a particular manner, taking snuff, \&c., merely to be taken notice of, is said to do it out of flash'; a 'NEEDY-MIZZLER [is] a poor ragged object of either sex; a shabby-looking person'; a 'SHARP [is] a gambler, or person, professed in all the arts of play; a cheat, or swindler'; 
a 'RAG-GORGY [is] a rich or monied man, but generally used in conversation when a particular gentleman, or person in high office, is hinted at; instead of mentioning his name, they say, the Rag-gorgy, knowing themselves to be understood by those they are addressing'. Another kind of flash man is the 'fancy-man', a pimp; the 'scamp' is a thief; then there is the 'beau-nasty', or 'slovenly fop'; the 'Duke of limbs' is 'a tall, awkward, ill-made fellow', while the 'real swell' (DJ XI, st. 17, line 134) is both a gentleman and a man of fashion..$^{22}$ These flash men had their consorts - the 'blowing' (DJ XI, st. 19 , line 151) or 'blowen' was a 'mistress of a gentleman of the scamp' - and queer sisters, the 'flash mob' inmates of the Female Factory who in 1840 rioted and staged witchy cabals in the hills outside Hobart. ${ }^{23}$

Another key source of flash language is Pierce Egan's Life in London (1821), which features the escapades of the well-heeled Tom and Jerry slumming it in the poorer districts. Using the language of racing, Egan produces a mock stud pedigree of 'a Dandy in 1820 . The Dandy was got by vanity out of Affectation - his dam, Petit-Maitre or Maccaroni, - his grand dam, Fribble - his great grand dam - Bronze - his great great grand dam, Coxcomb - and his earliest ancestor Fop. ${ }^{24}$ The parodic genealogy suggests that the dandy is a little tired, a little antiquated, not entirely flash. The dandy was then superseded by the flash man or 'Corinthian', which Grose's Dictionary defines as 'a frequenter of brothels'. The flash man and other relatives of the Londonate dandy are all commemorated in the new popular antiquarian genre of the urban lexicon, including Grose's Classical Dictionary and Vaux's A New Vocabulary of the Flash Language.

\section{Flash returns and lag fever}

James Hardy Vaux (1782-1841) was a professional thief, lag, and recidivist, who was transported three times to New South Wales (Figure 3.4). Originally a clerk, he was arrested in April 1800 for pilfering from his employers. He was acquitted on that charge, but soon after was sentenced to seven years' transportation for stealing a handkerchief. His father, a butler and house steward to an MP, seems to have used his contacts to arrange for his son to avoid the hulks and go straight to the transportation ship.

Vaux's Memoirs detail his pre-criminal career as a copying clerk - a member of London's new semi-professional class. His narrative celebrates the transformative power of reading as a means of self-improvement, describing how

during the course of a wild and dissipated life ... a portion of my time was always devoted to the perusal of books, and a part of my money, however hardly or dishonestly obtained, to the purchase of them: and to this moment I still consider them the most valuable property a man of my disposition can possess. ${ }^{25}$ 


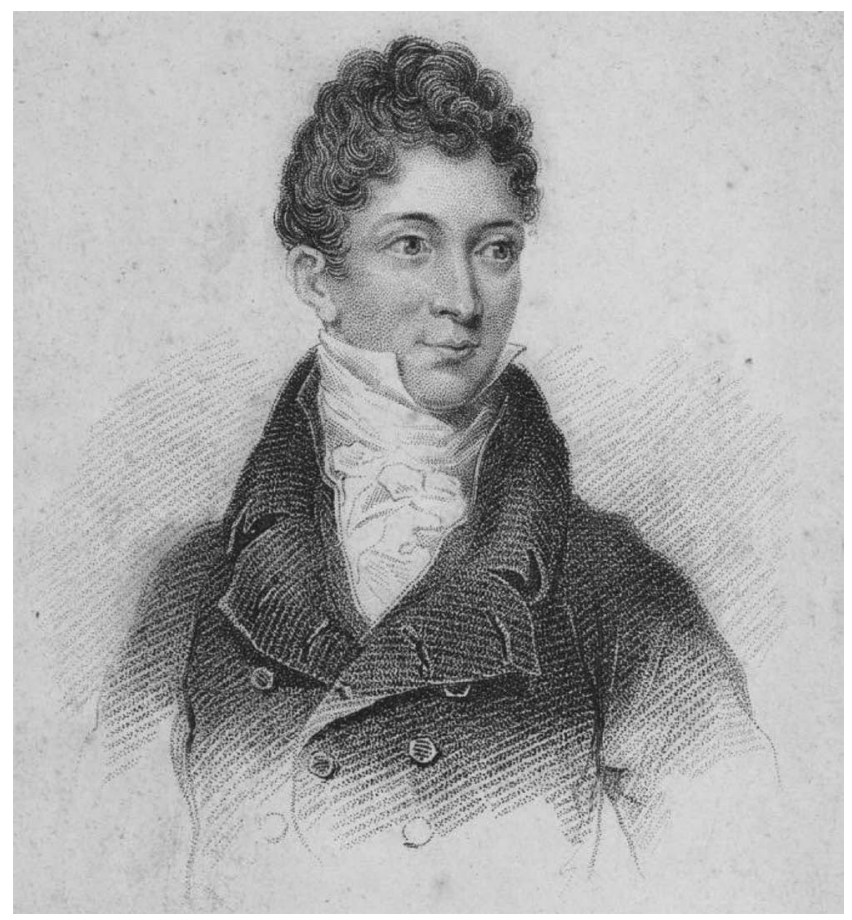

Figure 3.4 Artist unknown, 'Portrait of James Hardy Vaux', originally published in Knapp and Baldwin's New Newgate Calendar, c. 1825

The Memoirs were recognised as highly literate and literary. The London Magazine in 1827 described the book as 'one of the most singular that ever issued from the press' ${ }^{26}$ Vaux's fascination with language also produced his Vocabulary of the Flash, which was published with the Memoirs. The Vocabulary was dedicated to Vaux's former jailer, Thomas Skottowe, with the suggestion that it 'will afford you some amusement from its novelty; and that from the correctness of its definitions, you may occasionally find it useful in your magisterial capacity'. ${ }^{27}$

The flash language combined the new (slang) with the old (cant), and claimed ancient customary usage. Marilyn Butler observes that 'Grose's whimsical preface ... makes play with the idea of classicality', hence the reference to 'St. Giles' Greek'. ${ }^{28}$ As William Moncrieff writes in Tom and Jerry (1821), the stage adaptation of Life in London, 'FLASH, my young friend, or slang, as others call it, is the classical language of the Holy Land; in other words St. Giles' Greek'. ${ }^{29}$

Flash lexicons drew authority from flash's relationship to earlier slang languages. John Camden Hotten's Dictionary of Modern Slang, Cant, and 
Vulgar Words (1859) traces how during the Regency, 'Slang ... received numerous additions from pugilism, horse-racing, and "fast" life generally', and observes that it 'was generally termed FLASH language'. Hotten's Dictionary actively recirculates words used by rebels and revolutionaries as far back as the sixteenth century, taking as its epigraph a quote from Charles II's chaplain Robert South: 'Rabble-charming words, which carry so much wild-fire wrapt up in them'.$^{30}$ This linguistic retrofitting can be seen as activating a kind of lag fever, a popular retrospective avant-gardism charged with demotic bravura and the power of anachronism. This retroactivity makes the flash a peculiarly dynamic - even dialectical - vehicle of cultural lag, bristling against spatial and geographical backwardness, and highlighting the transformative elements of disjunction.

This term 'lag fever' figures in one sense the belatedness of the colonial world; it confirms the experience of penal transportation as a backward movement of space and time, bestowing the social identity of 'lags' and their backward state. ${ }^{31}$ But it can run both ways; its multiple uses show that the colonial lag can outrun the imperial centre, reflecting the metropole back in a less flattering light. Even Byron fantasised about being a settler in Van Diemen's Land, as he wrote to his agent: 'I have long had a notion of emigration from your worn out Europe - but am undecided as to the where South America - The United States - or even van Diemen's land - of which I hear much as a good place to settle in. ${ }^{32}$ Byron was then completing the draft of Canto XI, which he would send to John Murray in October 1822.

That the lag could charge the transformative elements of colonial disjunction is amply demonstrated by Vaux, whose convict career sees a pattern of release, relapse, and re-transportation. (He seems to have been the only prisoner transported to Australia as many as three times.) Vaux's story of transportation is one of departures and returns, with ongoing contact and cultural interpenetration between London and the colony. Vaux wrote his Memoirs and flash Vocabulary in Newcastle, known as 'the Hell of New South Wales', a place of secondary punishment where the most dangerous convicts were sent to dig in the coal mines. Military rule in Newcastle ended in 1823, shortly after Vaux's time there, and the area was opened up to farming.

Vaux's repeat offending consolidated a circuit between metropolis and colony. When he first published his Memoirs in 1819, he was connected to influential colonial figures such as Samuel Marsden and Barron Field, the author of the first Australian book of poetry, First Fruits (1819). Indeed, Field arranged for the manuscript to be published in London by John Murray. This flow between the metropole and the colony transformed Vaux into a recognisable literary icon and Australian type of rebel.

In a stage adaptation of Vaux's Memoirs by William Moncrieff, entitled Van Diemen's Land! Or Settlers and Natives (1830), Vaux features in the 
character list as 'a pupil of the Barrington School' (named after the pickpocket George Barrington), ${ }^{33}$ and compares the transported convicts' situation with that of 'our masters, the settlers':

we're transported here with more justice than they are; we come here for our sins, and they for their misfortunes; - they come here at their own expence, we at the government's; - they run all the risk - we share all the profit. I never worked so hard for my dinner as when I was obliged to steal it. ${ }^{34}$

The flash was by definition alert to structural injustice: 'to be flash to any matter or meaning, is to understand or comprehend it ... to put a person flash to any thing, is to put him on his guard, to explain or inform him of what he was before unacquainted with'. ${ }^{35}$

Vaux's iconic status is registered when his name appears in the 'Invocation' that opens Pierce Egan's Life in London (1821; originally serialised in 1820), a roll-call of literary influences and patrons, including John Murray:

But thou, O, MURRAY, whose classic front defies, with terrific awe, ill-starred, pale, wan, and shabbily clad GENIUS from approaching thy splendid threshold ... open thy doors, and take the unsophisticated JERRY HAWTHORN by the hand: and although not a CHILDE HAROLD in birth, a CORSAIR bold, or a HARDY VAUX, wretched exile; yet let me solicit thee to introduce him to thy numerous acquaintance. ${ }^{36}$

Here, Vaux's convict memoir, the narrative of the career criminal, is invoked as a source of authority on a par with the poetry of Lord Byron. The 'Invocation' reverses the flow of the lag and 'wretched exile' - not from metropolis to colony but the other way around, chiming with Byron's desire to leave 'worn out Europe'. Chiming here too is Byron's imagined transportation in Don Juan Canto III of the Lake Poets Robert Southey, William Wordsworth, and Samuel Taylor Coleridge, whose late political conservatism reneged on youthful Pantisocratic idealism: 'Such names at present cut a convict figure, / The very Botany Bay in moral geography' (DJ III, st. 94, lines 841-2). ${ }^{37}$ This was written in September 1819 (published in August 1821), possibly with Vaux's recently published convict memoir and flash Vocabulary at hand. By claiming Vaux's colonial memoir as an influence and inspiration for his account of London metropolitan life, Egan honours picaresque criminality. 'HARDY VAUX' rubs shoulders with CHILDE HAROLD and the CORSAIR - the brooding traveller and the pirate, who put into circulation the powerful form of Byronic scandalous celebrity. Egan's Life in London creates a specific intertextual relationship between the fabled Byronic mode of celebrity self-exile and the enforced mobility of penal transportation to colonial Australia.

Egan's Life in London is usually identified as the great sensation that popularised flash language and introduced this dynamic currency of common 
social life to the upper classes; but as its 'Invocation' demonstrates, Egan's version in fact followed Vaux's colonial deployment of the flash, as did Byron's flash canto of Don Juan. There was a significant interpenetration between metropole and periphery. Egan figures publishing as a form of social patronage, invoking the doors of Murray's publishing house to effect an introduction: of the unsophisticated Jerry to his 'numerous acquaintance' by the powerful Murray, the epicentre of worldly London contacts.

Despite Egan's figure of Murray taking literary newcomers by the hand, the publisher's relationships with Vaux and Byron were not a tireless flow of bonhomie. Murray published Vaux's Memoirs on 12 January 1819, six months before the first two cantos of Byron's Don Juan. He published both books with a sense of ambivalence; tellingly, both were later published by the radical John Hunt. Murray put his name to the first edition of Vaux's memoir, but quickly dropped the connection. ${ }^{38} \mathrm{He}$ was similarly awkward about the first two cantos of Don Juan, which he published without his name (thereby giving pirates carte blanche). In April 1829, Vaux absconded and went to Ireland. The next year he was convicted of passing forged bank notes, or 'queer screens'. His death sentence was commuted to transportation for seven years, and he returned to Sydney. In 1841, he disappeared from the record, but his Memoirs and Vocabulary of the Flash had far-reaching influence.

\section{Dandified silhouettes and sartorialised violence}

The D'Orsay-Byron dandy silhouette has another afterlife in colonial Australia through the colonial functionary William Romaine Govett (1808-48), a surveyor in New South Wales. A sketchbook album belonging to Govett, held at the National Library of Australia, includes a pen and ink copy of Maclise's 1834 sketch of D'Orsay, together with copies of other literary identities - Blessington, Thomas Egerton (Jane Austen's first publisher), Leigh Hunt, William Bowles, and Laetitia Landon. They seem to be original handdrawn copies of the Maclise illustrations, but they also suggest in places a process of tracing, with the intermediation of print and pen, making it difficult to determine whether they are manuscript or print. The image of D'Orsay has a caption added: 'THE OBSERVED OF ALL OBSERVERS' (Figure 3.5). ${ }^{39}$ There are sketches and watercolours of Australian flora and fauna, including kangaroos and the 'Head of an eagle shot by me on the banks of the Wollondilly River, New South Wales, $8^{\text {th }}$ April 1828'. In Govett's sketchbook, the literary lions of Regency London share the stage with the stars of the Australian animal kingdom, and the Regency metropolis is interpenetrated by the colonial peripheries. Govett uses flash words, such as 'Spanker' (the flash name for horse) for his dog, which was bitten by a snake. ${ }^{40}$ 


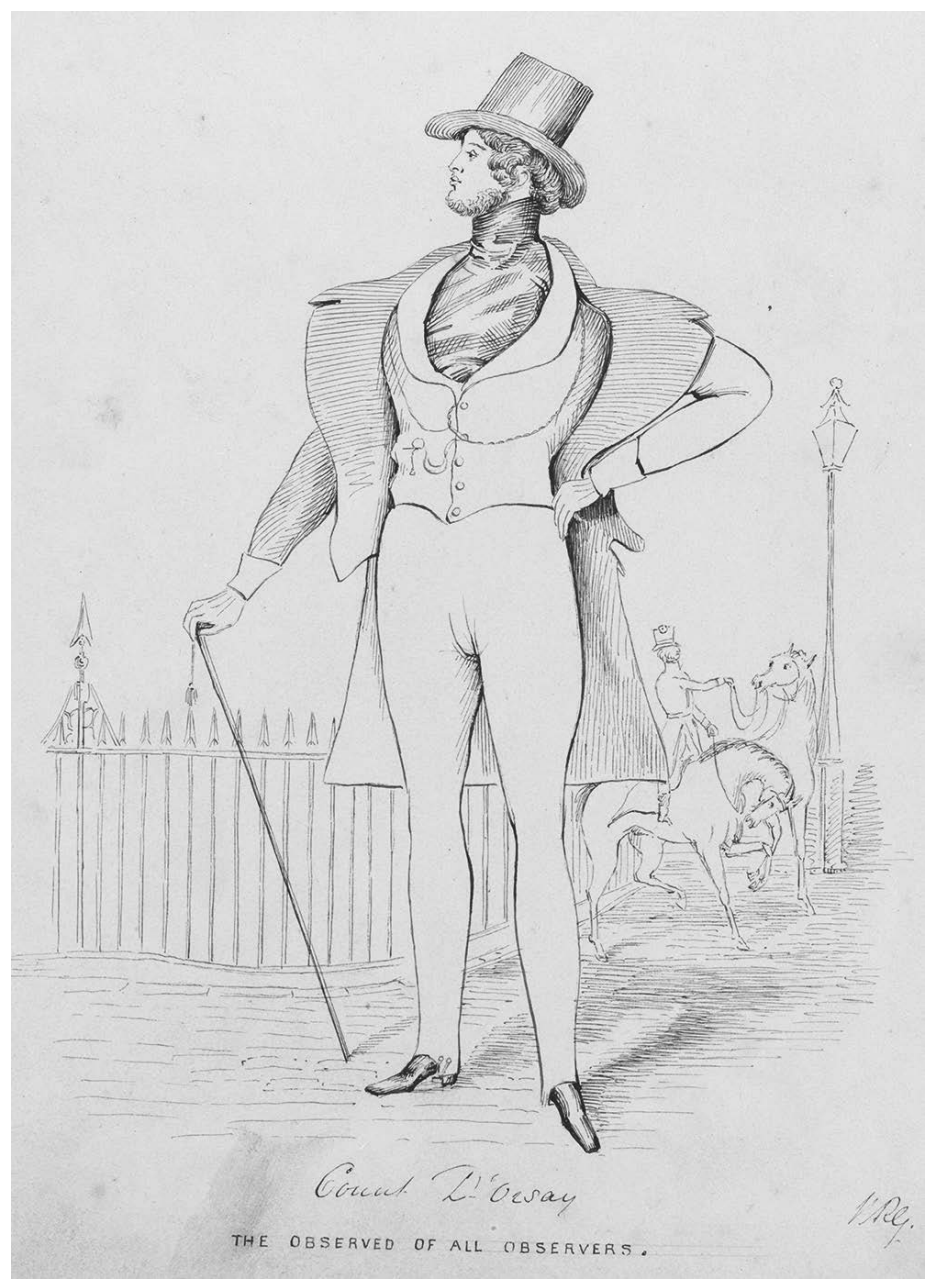

Figure 3.5 William Romaine Govett, copy of Daniel Maclise, 'Alfred, Count D'Orsay', 1834, pen and ink, 1843?

Govett was an assistant to the New South Wales Surveyor, Sir Thomas Mitchell. Govett's Leap, a waterfall with a 1,000-metre drop in the Blue Mountains, outside Sydney, was named by Mitchell, who referred to Govett as 'a wild young man who needed control' ${ }^{41} \mathrm{He}$ was such a wild young man that popular legend confused him with a local bushranger; as late as 1871, the Sydney Mail described Govett as 'a queer card', a 'Swell', and 'a convicted felon', who was 'lagged for robbery', and who had taken his own life by throwing himself down a gorge. ${ }^{42}$ In fact, Govett was made redundant in 
1834 and returned to England, where he died in 1848 apparently of natural causes. Nevertheless, this legend of the 'wild young man' has an added resonance when read against an entry by Govett in a notebook and sketchbook detailing the discovery of the cataract:

It was an amusement with me always when I approached the edge of these precipices, to loosen large masses of rock, and by the assistance of the men lying on their backs, and pushing with their feet, to upset them into the abyss below - and one could form a tolerable judgement of the frightful depth they had to fall before they came in contact with any thing, from observing the time of silence, from the instant of their dislodgement, until they struck, and reechoing thundered from rock to rock and valley to valley, resounding again and against the more distant walls of the gully. ${ }^{43}$

Govett's 'amusement' suggests a particular experience of space, configured by temporal effects of lag, delay, and deferral, where lag is experienced as a form of vertiginous sublimity. This curious temporal experience of 'observing the time of silence' includes the vicarious thrill of experiencing 'the frightful depth' at a distance, as Govett hears the rock striking in the distance, experienced as a physical sensation: lag as exhilaration.

As the colonial 'wild young man', Govett both copies and displaces the late Regency dandy type, D'Orsay - that iconic silhouette of modern urban masculinity inaugurated in 1790s Mayfair, transformed into other dandy kinds (buck, swell, flash man, or fancy man), and then expatriated or transported to the colonies. When Govett returned to England in 1834, he wrote twenty articles on Australia for the Saturday Magazine, including accounts of Indigenous-settler contact that commented on white brutality, and a description of a corroboree attuned to masculine gesture, dress, and ritual.

Govett's superior in New South Wales thereafter became the highly decorated Major Thomas Mitchell, after whom the Major Mitchell Cockatoo was named: 'Few birds,' Mitchell wrote, 'more enliven the monotonous hues of the Australian forest than this beautiful species whose pink-coloured wings and flowing crest might have embellished the air of a more voluptuous region. ${ }^{44}$ Mitchell embodied another form of dandy: the military man. He had been a general in the Peninsular Wars (against Napoleon) under the Duke of Wellington, who became the nineteenth century's most famous military celebrity. Recalling his career under Wellington, Mitchell made it a practice to name colonial sites after battle sites in Spain. ${ }^{45} \mathrm{He}$ also had a problematic relationship with Indigenous Australians, which is commemorated in a controversial portrait, a silhouette lithograph by William Fernyhough (Figure 3.6). ${ }^{46}$

In this portrait, which echoes a famous silhouette of the Duke of Wellington, Mitchell is presented with a riding crop and spurs. Most strikingly, he is looking at a portrait of the Wiradjuri man John Piper, his guide and 


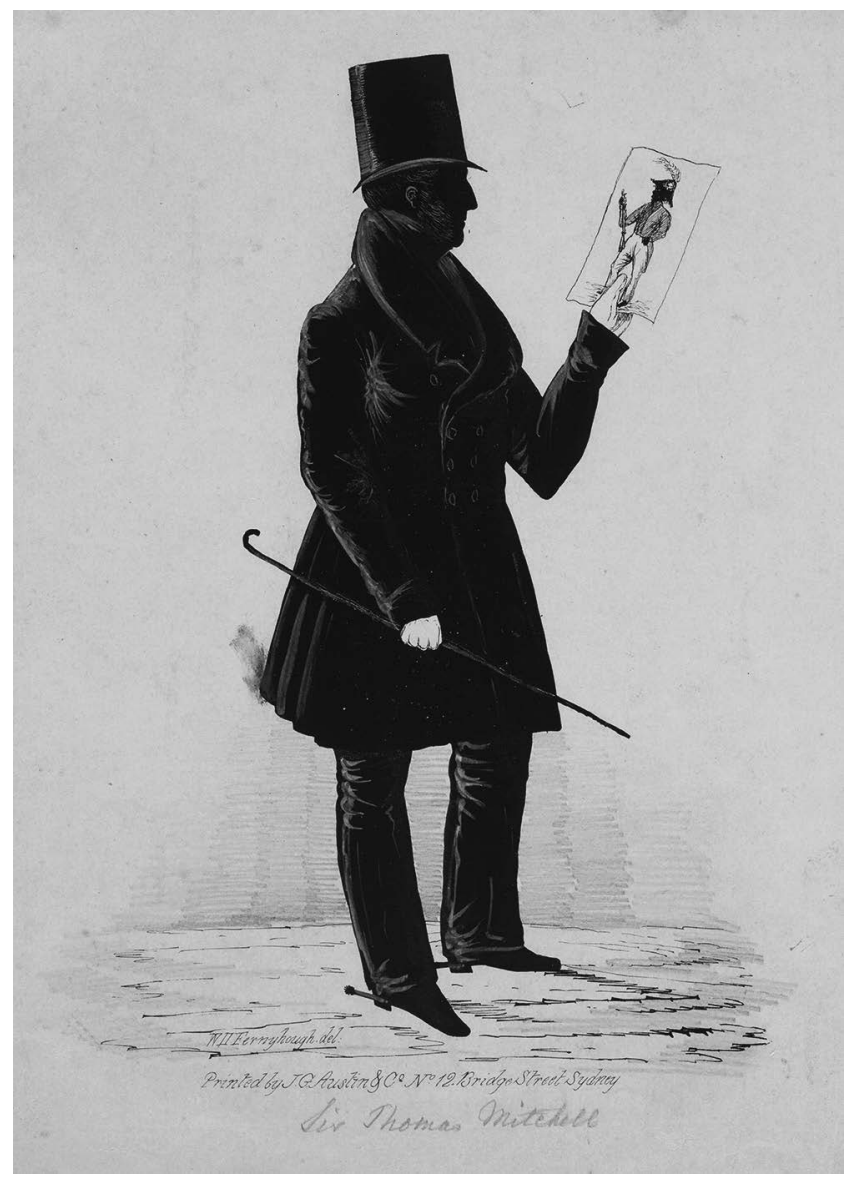

Figure 3.6 William Fernyhough, 'Portrait of Sir Thomas Mitchell', in Album of Portraits, Mainly of New South

Wales Officials, lithograph, 1836

interpreter on his third expedition into the interior. This portrait within a portrait reproduces Fernyhough's original portrait of Piper, 'the native who accompanied Major Mitchell in his expedition to the interior' (Figure 3.7).47 In it, Piper is 'posing proudly with the accoutrements of settler regard that had been given to him by Mitchell', of which Mitchell wrote: ${ }^{8}$ 'I clothed him in my own red coat, and I gave him also a cocked hat and feather, which had once belonged to Governor Darling' - a ritual gifting that suggests something more complex than the passing on of cast-offs. ${ }^{49}$

But the plot thickens. In December 1836, the executive council investigated Mitchell for the killing of seven Aboriginal people at Dispersion 
Mountain. In his defence, Mitchell claimed that Piper had warned him of an impending Aboriginal attack. David Hansen suggests that the print may have been intended 'as a reminder ... of Piper's responsibility and Mitchell's innocence'. ${ }^{50}$ So the image mediates a contemporary controversy around frontier violence. It suggests how polite colonial settler culture is allied with statesanctioned violence through rituals of 'decoration', patronage, and intimate recognition as a form of social control. Complex, ambivalent, and powerful, this mass-produced silhouette takes on the symbolic and didactic functions of more elevated forms of portraiture. In staging an intimate reciprocity between Mitchell and Piper (similarly featured in the frontispiece to Mitchell's Expeditions), it simultaneously salutes a traditional martial form of homosocial friendship and inscribes the tensions that marked that relationship, which culminated with Piper's betrayal by Mitchell. And while in the investigation Mitchell's defence made much of having been reluctant to shoot, in his Expeditions into the Interior (2nd edn 1839) he openly glorifies the violence, recalling how he named the hill in commemoration of the events. ${ }^{51}$

This curious double portrait may be no less exploitative for being intimate, but it also functions as a vehicle of Indigenous self-assertion. As Grace Karskens argues, in early colonial Australia, some Aboriginal men, like Piper, embraced European military clothing to signify their identification with white men and their superior social status. ${ }^{52}$ The jackets they wore were important emblems of masculine power. Mitchell also rewarded Piper with the gift of a breastplate, and the moniker 'King'; but Piper pointedly declared that he did not want to be known as a 'King' but as the 'Conqueror' of the inland. ${ }^{53} \mathrm{Nev}$ ertheless, it is telling that in Fernyhough's image, the 'Conqueror' appears in miniature, held in the palm of Mitchell's hand. After his fame, when people gave him money, Piper 'purchased silk handkerchiefs, and wore them in his breast', as Mitchell notes approvingly: 'to his great credit, he abstained from any indulgence in intoxication, looking down, apparently with contempt, on those wretched specimens of his race, who led a gipsy life about Sydney'. ${ }^{54}$

These portraits demonstrate clothing's potent agency; as Linda Colley writes of the Napoleonic Wars: 'Never before or since have British military uniforms been so impractically gorgeous ... And the more exclusive a regiment an officer belonged to, and the higher his rank, the more dazzling his uniform was likely to be. In every sense he was dressed to kill. ${ }^{55}$ The dazzling red coat is an enactment - and an enigmatic conjunction - of power and violence, resonating in the colonies like the echo of Mitchell's naming practices. The red coat and its sartorial power is a key protagonist in the history of colonial Australia, where, in Margaret Maynard's words, 'what was at first virtually a military prison was to be transformed, within a single generation, into a fully organised capitalist society'. ${ }^{56}$ The dandy military man and the colonial functionary had a significant role in this transformation, as did the 


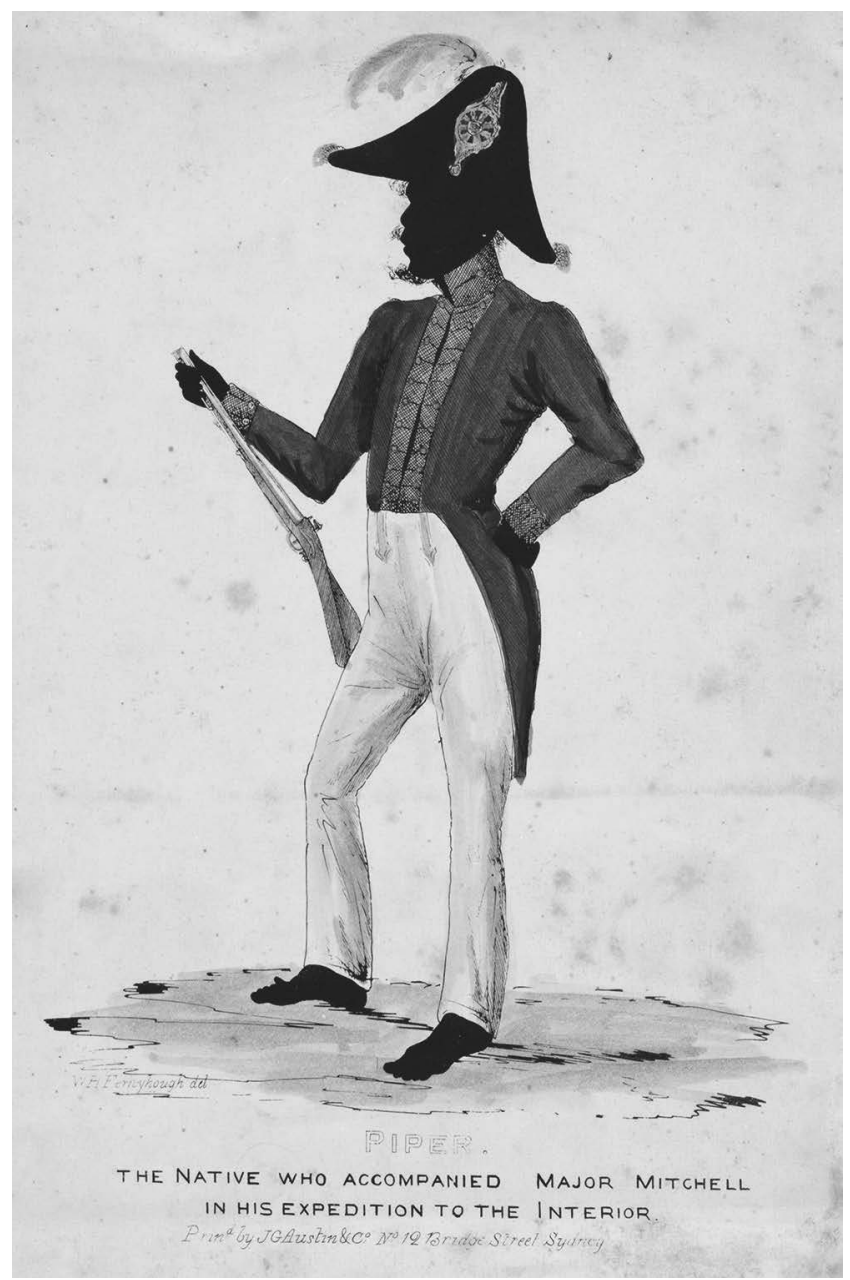

Figure 3.7 William Fernyhough, 'Piper, the native who accompanied Major Mitchell in his expedition to the interior', in A Series of Twelve Profile Portraits of the Aborigines of New South Wales, lithograph, 1836

convict dandy and his Indigenous guide and interpreter. 'Gentlemen convicts mixed freely in elite social circles and often lived like men of fashion', spending their earnings freely, as Jane Elliott notes. ${ }^{57}$

This relationship between labour and self-fashioning is documented in the journal of the labourer Evan Evans, who records that on 18 October 1803 he received ' 1 Handkerchief in payment for felling straggling trees at the lagoon'; he also purchased silk handkerchiefs, black silk and ribbon, 
duck trousers, and a dimity petticoat for his wife. As Elliott writes, 'labourers in New South Wales chose to spend large amounts of their earnings not merely on clothing but on good quality things, which would normally have been considered the prerogative of members of the classes above them'. ${ }^{58}$ Men's shirts were made of the finest muslin made in India 'even in the very early days, when it seemed that the colony was nothing more than a prison'. ${ }^{59}$

Such items of dandy apparel embody what Arjun Appadurai termed 'the long-distance journey of commodities' that marked the Euro-colonial worldsystem, in which the colonies became stalled as the metropolises' past. ${ }^{60}$ Nevertheless, as part of this journey, new worlds of the future refract the imperial centre. The convict's new-found ability to purchase silk and selffashion as a dandy marks his escape from impoverishment, filling his stomach and his 'flesh-bag' - the evocative flash word for shirt.

\section{'A total smash': scandalous celebrity and Regency modernity}

A sensational case study of criminal celebrity and upward convict social mobility is offered by the genteel criminal Thomas Griffiths Wainewright (1794-1847), an English artist, suspected poisoner, and convicted forger, who in 1837 was transported to Van Diemen's Land, where he was eventually granted a ticket of leave in 1845 and became a noted society portrait painter. His trial papers described him as a 'gentlemanly man', 'wearing moustaches' ${ }^{61}$ In a self-portrait entitled 'Head of a Convict', Wainewright openly models the figure of the convict dandy, with his 'jacket turned up in a slightly Byronic fashion'. ${ }^{62}$

In her fine study of colonial Australian portrait drawings, Joanna Gilmour refers to Wainewright as 'the best trained, best connected and most accomplished' of 'Australia's convict artists' ${ }^{63}$ In his 1844 petition for a ticket of leave, Wainewright 'submits, with great diffidence ... A Descent, deduc'd thro Family Tradition \& Edmonstone's Heraldry, from a stock not the least honoured in Cambria - Nurtured with all appliances of ease and comfort'. His 'modest competence' in 'pen \& brush' had brought him 'to the notice $\&$ friendship of men whose fame is European' ${ }^{64}$ Indeed, his grandfather Ralph Griffiths founded the Monthly Review, and Wainewright himself wrote for the London Magazine, producing art reviews under the pseudonym Janus Weathercock, in the character of a leisured dandified connoisseur. He claimed to have enjoyed the friendship of Charles Lamb and the acquaintance of William Hazlitt and Thomas Carlyle. Trained by the fashionable London portrait painter Thomas Phillips, who painted Byron in his Albanian dress, Wainewright was apprenticed to Phillips' studio, where he made a copy of Phillips' iconic 'cloak' portrait of Byron, Portrait of a Nobleman (1814). 
Wainewright's petition makes much of the colony's bad language: 'Take pity, Your Excellency! and grant me the power to shelter ... my ears from a jargon of filth \& blasphemy that would outrage the cynism [sic] of Parny himself.' The reference is to Éveriste de Parny, author of Les Poésies érotiques (1778), which was banned by the French government in $1827 .{ }^{65}$ Granted his ticket of leave in 1845 , Wainewright established himself as a portrait painter and was commissioned by a number of prominent families in Van Diemen's Land. As Gilmour notes, he associated with settler colonials, 'middling public servants or those of less-elevated social origins ... more anxious to present themselves as gentrified ${ }^{6}{ }^{66}$ Through his portraits, which he signed TGW, Wainewright documented and collaborated in this process of colonial making and remaking.

One of his clients was Major Robert Power, Lady Blessington's brother, who had arrived in 1840 and became Surveyor General of Van Diemen's Land. Power commissioned a portrait of his daughter, Margaret, who shared her aunt's maiden name. By February 1847, this portrait had found its way to London, where Lady Blessington showed it to her guests at Gore House (apparently including Charles Dickens, who was fascinated by Wainewright and later based a story on him, Hunted Down). ${ }^{67}$ Gore House was Blessington's last London home before she was forced to flee to escape her creditors after the Irish potato disease ate up her remaining jointure; she and D'Orsay went into exile in France, where they lived until their deaths.

Wainewright's portrait of Blessington's niece in Blessington's home embodies the interpenetration of the liminal yet transformative Regency cultures of scandalous celebrity, exile, colonial settlerdom, and convictism. It may have been one of the portraits sold in 1849 in the break-up of Gore House (the Royal Albert Hall now occupies the site). As her contemporary biographer wrote: 'here was a total smash, a crash on a grand scale of ruin, a compulsory sale in the house of a noble lady, a sweeping clearance of all its treasures' ${ }^{68}$ In The Idler in France, Blessington herself romanced the auction as a genre of ruins. Doing the rounds of the curiosity shops on the Quai D'Orsay, she purchased an amber vase said to have belonged to the Empress Josephine: 'When I see beautiful objects collected together in these shops, I often think of their probable histories, and of those to whom they belonged ... the gages d'amour are scattered all around. But the givers and receivers, where are they? Mouldering in the grave, long years ago. ${ }^{69}$ The same fate awaited her own possessions: 'the rare and beautiful bijouterie which I have collected with such pains, and looked on with such pleasure, will probably be scattered abroad, and find their resting place not in gilded salons, but in the dingy coffers of the wily brocanteur' ${ }^{70}$

In this chapter, I have sought to highlight the transformative elements of colonial lag in the work of scattering abroad. Like the shadow art of the silhouette medium - proleptic of the new media of photography, cinema, 
and screen projection, but nostalgic and retrospective - this eerie gentleman of the shade, Wainewright, models simultaneously a 'real time' Regency dandyism that conjures its own belated forms and a newly transformed dandy that transports the shadowy pasts and arriviste careers of scandalous success into a new arena of global modernity, hosting a complex traffic between metropolis and colony, respectability and unrespectability, fame and notoriety, settler colonialism and convictism.

The story of new Regency masculine social identities - European rentier expatriates, respectable men, swells, flash men, wild colonial men, gentlemen of the shade, convicts broken or remade anew through tickets of leave, and their Indigenous guides and brokers, who then became their own self-made colonial men - is not a simple story of supersession; it is one of intermediation and interpenetration. In this sense, rather than being the Regency's distant other - at the far remove of an irreversible lag - Botany Bay, Newcastle, and Van Diemen's Land can be seen as realising the Regency as a model of global modernity. If the transported flash language, like the lag fever it indexes, figures the belatedness of the colonial world, it does so with a twist: registering an energy and dynamism of the colonial peripheries, as a charged capacity for influencing, transforming, and outrunning Britain's imperial metropolitan centre, and possibly even providing the refracting lenses - barnacles, or queer screens - through which to see it more clearly.

\section{Acknowledgements}

The research and writing of this chapter were supported by the Australian Research Council. I also thank Jenny Lee, Caitlyn Lehmann, Gillian Russell, and the editors of this volume, Sarah Comyn and Porscha Fermanis.

\section{Notes}

1 Quoted in Terence Allan Hoagwood and Kathryn Ledbetter, 'Colour'd Shadows': Contexts in Publishing, Printing, and Reading Nineteenth-Century British Women Writers (Basingstoke: Palgrave Macmillan, 2005), p. 54.

2 Mrs Carlyle, quoted in Michael Sadleir, Blessington-D’Orsay: A Masquerade (London: Constable, 1947) p. 280; Mrs Newton Crosland, quoted in Sadleir, Blessington-D'Orsay, p. 268; Mrs Carlyle, quoted in Sadleir, Blessington-D'Orsay, p. 279; Gronow, quoted in Sadleir, Blessington-D’Orsay, p. 278.

3 Lord Byron, Byron's Letters and Journals, ed. Leslie Marchand, 12 vols (London: John Murray, 1980), 10:136-7.

4 For details of the Byron drawings traditionally attributed to D'Orsay, see Annette Peach, Portraits of Byron (London: The Walpole Society, 2000), pp. 117-20. 
5 Christopher Breward, Fashioning London: Clothing and the Modern Metropolis (Oxford: Berg, 2004), p. 28.

6 Jessica R. Feldman, Gender on the Divide: The Dandy in Modernist Literature (Ithaca: Cornell University Press, 1993), p. 2.

7 Gregory Dart observes that the 'thick verbal texture' of the flash language created 'a kind of classless language, a polyglot vocabulary that was not tied down to any particular social milieu'. 'Flash Style: Pierce Egan and the Literary Culture of the 1820s', History Workshop Journal, 51 (2001), 191.

8 Peter Cunningham, Two Years in New South Wales, ed. David S. Macmillan (1827; Sydney: Angus \& Robertson, 1966), p. 209.

9 Francis Grose, Classical Dictionary of the Vulgar Tongue (London, 1811), n.p.; James Hardy Vaux, A New and Comprehensive Vocabulary of the Flash Language (London: Printed by W. Clowes, 1819), p. 185.

10 Grose, Classical Dictionary (1811), n.p. Grose also lists 'Bay Fever' as an illness shammed to avoid being sent to Botany Bay.

11 Vaux, Vocabulary, p. 185.

12 Julie Coleman, A History of Cant and Slang Dictionaries: Volume 2: 1785-1858 (Oxford: Oxford University Press, 2004), p. 139.

13 Vaux, Vocabulary, p. 155.

14 See Vaux, Vocabulary, p. 165, and Grose, Classical Dictionary (1811), n.p., given as an Irish term.

15 Francis Grose, A Classical Dictionary of the Vulgar Tongue (London: Printed for S. Hooper, 1785), n.p.

16 See Grose's reference to 'those late fashionable words, a Bore and a Twaddle, among the great vulgar, Maccaroni and the Barber, among the small'; Classical Dictionary (1811), p. ii.

17 All in-text references are to Lord Byron, Don Juan, The Complete Poetical Works, ed. Jerome J. McGann (Oxford University Press, 1986).

18 Grose, Classical Dictionary (1785), pp. iii, viii.

19 The 1785 edition of Grose's Classical Dictionary has an entry for 'MOON MEN', defined as 'gypsies'.

20 William Noah, quoted in Grace Karskens, The Colony: A History of Early Sydney (Sydney: Allen \& Unwin, 2009), p. 17.

21 Grose, biographical note at http://adb.anu.edu.au/biography/grose-francis-2130 (accessed 12 February 2020). See also Karskens, The Colony, pp. 87, 90, 118-21, 138.

22 Vaux, Vocabulary, pp. 174, 191, 205, 200-1, 241.

23 See Kay Daniels, 'Feminism and Social History', Australian Feminist Studies, 1 (1985), 9.

24 Pierce Egan, Life in London (1821; Cambridge: Cambridge University Press, 2011), p. 42.

25 Memoirs of James Hardy Vaux. Written by himself. In two volumes (London: Printed by W. Clowes, 1819), pp. 15-16.

26 'Memoirs of James Hardy Vaux', London Literary Magazine, 19 (September 1827), 55.

27 Vaux, Memoirs, p. 152. 
28 Marilyn Butler, Mapping Mythologies: Counter-Currents in Eighteenth-Century British Poetry and Cultural History (Cambridge: Cambridge University Press, 2015), p. 135.

29 W. T. Moncrieff, Tom and Jerry (1821). Moncrieff also wrote a burletta called The Dandy Family and the Ascot Jockies (1818). See advertisement, Morning Post (15 June 1818), n.p.

30 John Camden Hotten, Dictionary of Modern Slang, Cant, and Vulgar Words (London: John Camden Hotten, 1859), p. 50.

31 In his seminal analysis, Frantz Fanon critiques the status of the postcolonial black man as always 'too late': Black Skin, White Masks (1952; London: Pluto Press, 1986), pp. 1, 91, 92.

32 Byron's Letters and Journals, 9:215.

33 On Barrington's fame, see Nathan Garvey, The Celebrated George Barrington: A Spurious Author, the Book Trade, and Botany Bay (Potts Point: Hordern House, 2008).

34 W. T. Moncrieff, Van Diemen's Land: An Operatic Drama in Three Acts (London: John Cumberland, n.d. [1831]), p. 22.

35 Vaux, Memoirs, p. 174.

36 Egan, Life in London, p. 8.

37 Byron's ‘Botany Bay in moral geography' seems to refer to A New Moral System of Geography, Containing an Account of the Different Nations Ancient and Modern (Bath: Printed for G. Riley, 1790), which features an outline of Botany Bay for children (pp. 181-7). The Hordern House website refers to it as 'the first educational work to refer to settled Australia', www.hordern.com/pages/books/ 3506031/new-moral-system/a-new-moral-system-of-geography-containingan-account-of-the-different-nations-ancient-and-modern (accessed 14 April 2020).

38 Noel McLachlan notes that there is 'virtually no trace left of the original edition bearing Murray's name': The Memoirs of James Hardy Vaux (London: Heinemann, 1964), p. xxi. As the Australian Dictionary of National Biography entry on Vaux notes, Barron Field 'arranged for its publication in London by John Murray, along with the slang dictionary, but Murray's imprint does not appear on most extant copies'.

39 ANL Rex Nan Kivell Collection, PIC T2306 NK5991/2 LOC NL Shel. The sketchbook has been digitised and is catalogued as though a printed item; but the images appear to be a series of original pen and ink copies of the lithograph etchings from Fraser's, all initialled WRG on the bottom right-hand side.

40 According to the 1859 Dictionary of Modern Slang, 'Cant is old; Slang is always modern and changing. To illustrate the difference: a thief in Cant language would term a horse a PRANCER or a PRAD, - while in slang, a man of fashion would speak of it as a BIT OF BLOOD, or a SPANKER.'

41 Thomas Mitchell, 'Report of Surveyor General', ML, A2146, 1832, NSW State Archives and Records.

42 Sydney Mail and New South Wales Advertiser (11 March 1871), p. 40; (18 March 1871), p. 87; (11 March 1871), p. 40. 
43 William Romaine Govett, notebook and sketchbook, http://acms.sl.nsw.gov.au/_ transcript/2012/D14753/a5504.html (accessed 7 March 2020).

44 Mitchell quoted in John Gould, Handbook to the Birds of Australia, vol. 2 (London: John Gould, 1865), p. 6.

45 See Paul Carter, The Road to Botany Bay (London: Faber, 1987), p. 118. See also Christine Wright, Wellington's Men in Australia: Peninsular War Veterans and the Making of Empire c. 1820-40 (Basingstoke: Palgrave Macmillan, 2011).

46 William Fernyhough, Album of Portraits, Mainly of New South Wales Officials (1836).

47 William Fernyhough, A Series of Twelve Portraits of Aborigines of New South Wales (Sydney: J. G. Austin, 1836).

48 David Hansen, “Another Man’s Understanding”: Settler Images of Aboriginal People', in Cathy Leahy and Judith Ryan (eds), Colony: Australia 1770-1861 / Frontier Wars (Melbourne: National Gallery of Victoria, 2018), pp. 108-19.

49 On Piper's clothes as 'cast off', see Elisabeth Findlay, 'Peddling Prejudice: A Series of Twelve Profile Portraits', Postcolonial Studies, 16:1 (2013), 2-27.

50 Hansen, “"Another Man's Understanding”, p. 319 n.23.

51 Thomas Mitchell, Three Expeditions into the Interior of Eastern Australia, Second edition, Carefully Revised, 2 vols (London: T. \& W. Boone, 1839), 2:1104.

52 See Grace Karskens, 'Red Coat, Blue Jacket, Black Skin: Aboriginal Men and Clothing in Early New South Wales', Aboriginal History, 35 (2011), 1-36.

53 In the same series by Fernyhough, Bungaree is referred to explicitly as 'King', appearing with a 'King Bungaree' breastplate around his neck.

54 Mitchell, Three Expeditions, 2:338.

55 Linda Colley, Britons: Forging the Nation 1707-1837 (New Haven: Yale University Press, 1992), p. 19.

56 Margaret Maynard, Fashioned from Penury: Dress as Cultural Practice in Colonial Australia (Cambridge: Cambridge University Press, 1994), p. 9.

57 Maynard, Fashioned from Penury, p. 18; Jane Elliott, 'Was There a Convict Dandy? Convict Consumer Interests in Sydney, 1788-1815', Australian Historical Studies, 26 (1994), 373-92.

58 Elliott, 'Was There a Convict Dandy?', 385.

59 Elliott, 'Was There a Convict Dandy?', 387.

60 Arjun Appadurai, 'Disjuncture and Difference in the Global Cultural Economy', in Bruce Robbins (ed.), The Phantom Public Sphere (Minneapolis: University of Minnesota Press, 1993), p. 269.

61 Quoted in Andrew Motion, Wainewright the Poisoner (New York: Alfred A. Knopf, 2000), p. 182.

62 Annette Peach, 'Wainewright, Thomas Griffiths [pseuds. Janus Weathercock, Cornelius van Vinkbooms]', n.p., https://doi.org/10.1093/ref:odnb/28403 (accessed 7 March 2020).

63 Joanna Gilmour, Elegance in Exile: Portrait Drawings from Colonial Australia (Canberra: National Portrait Gallery, 2012), p. 153.

64 Thomas Griffiths Wainewright, petition for ticket of leave to Governor Wilmot, 16 May 1844, State Library of NSW Aw 15, p. 2. 
65 Wainewright, petition for ticket of leave, p. 3.

66 Gilmour, Elegance in Exile, p. 156.

67 See Jonathan Curling, Janus Weathercock: The Life of Thomas Griffiths Wainewright (London: Nelson, 1938).

68 R. R. Madden, The Literary Life and Correspondence of the Countess of Blessington, 3 vols (London: T. C. Newby, 1855), vol. 1, pp. 203, 205.

69 Madden quoting the Countess of Blessington, The Idler in France, 2nd edn, 2 vols (London: Henry Colburn, 1842), vol. 2, pp. 202-3.

70 The Idler in France, pp. 59, 57 for 'gages d'amour'. 